\title{
INITIAL PUBLIC OFFERING (IPO) OF CAPITAL MARKET AND CAPITAL MARKET COMPANIES IN INDONESIA
}

\author{
Hartana \\ Presiden Direktur Sinar Mas Jakarta \\ Email : hartana_palm@yahoo.com
}

\begin{abstract}
From the aspect of Capital Market Law, the Initial Public Offering (IPO) conducted by PT. Dian Swastatika Sentosa Tbk (PT. DSS Tbk) is legitimate and has complied with all the provisions governing this matter. This can be seen in a series of stages of the IPO implementation carried out by PT. DSS Tbk. Likewise, if viewed from the legal aspects of Mineral and Coal Mining, it does not indicate any contradiction with the article governing Coal Mining if it is associated with the IPO process of PT. DSS Tbk. In conducting the IPO, PT. DSS Tbk does not experience significant obstacles. The only obstacles faced are small bureaucratic obstacles and policies can be overcome by the active role of Bapepam-LK. This shows that Bapepam-LK has acted as a dynamic supervisor.
\end{abstract}

Keywords: Initial Public Offering, PT. Dian Swastatika Sentosa Tbk, Mining Law, Capital Market Law

\begin{abstract}
Abstrak
Dari aspek Hukum Pasar Modal, Initial Public Offering (IPO) yang dilakukan oleh PT. Dian Swastatika Sentosa Tbk (PT. DSS Tbk) sah dan telah mentaati semua ketentuan yang mengatur hal tersebut. Hal ini terlihat dalam serangkaian tahapantahapan pelaksanaan IPO yang dilakukan oleh PT. DSS Tbk. Demikian juga jika ditinjau dari aspek hukum Pertambangan Mineral dan Batubara tidak menunjukkan adanya pertentangan dengan pasal yang mengatur mengenai Pertambangan Batubara apabila dikaitkan dengan proses IPO PT. DSS Tbk. Dalam pelaksanaan IPO, PT. DSS Tbk tidak mengalami hambatan yang berarti. Hambatan yang dihadapi hanyalah hambatan-hambatan kecil yang bersifat birokrasi dan kebijakan sudah dapat diatasi dengan peran aktif dari Bapepam-LK. Hal ini menunjukkan bahwa Bapepam-LK telah bertindak sebagai pangawas yang dinamis.
\end{abstract}

Kata kunci : Initial Public Offering, PT. Dian Swastatika Sentosa Tbk, Hukum Pertambangan, Hukum Pasar Modal

\section{Introduction}

The Capital Market is essentially a market that is not much different from the traditional markets that have been known, where there are traders, buyers, and also bargaining prices. Law Number 8 of 1995 concerning Capital Markets has outlined 
that Capital Markets have a strategic position in national economic development. The growth of a Capital Market depends on the performance of the securities company. To coordinate capital, technical support, and human resources in Capital Market development, effective leadership is needed. Companies must establish close cooperation to create markets that are able to provide various types of products and investment alternatives for the community.

To develop securities industry infrastructure, a large investment is needed. The investment depends on the economic benefits that can be obtained by the entrepreneurs. Factors that can reduce the amount of investment that can be needed to build infrastructure and reduce operating costs of securities companies, will encourage the development of the Capital Market through increasing the survival of Securities Companies. Such developments can be achieved if these factors are also able to produce safe and high-quality investment services and alternatives, especially in providing optimal services to investors so that their development will greatly affect the interest of prospective new investors who want to try investing in the Market. Capital.

The Stock Exchange continues to grow as we get older, and even more conditions show that the same effect has a lot of interest. The rush of public response and the ever increasing number of companies that are Go Public is a manifestation of the progress of the Stock Exchange. The development of the Stock Exchange that is happening now is thanks to the struggle of BAPEPAM-LK, a company that promotes its shares, the Government, Supporting Institutions, and the community that helped enliven stock trading and participated in investing excess funds. Compared to the stock exchange situation around 10 years ago, the current situation is indeed far different. The development is quite rapid and unexpected. But that does not mean the stock exchange goes smoothly without obstacles. Many things happened that colored the ups and downs of the life of stock exchanges in Indonesia. If the nation's social, political or economic conditions are disturbed and unstable, of course the condition of the stock exchange is greatly affected

The Indonesian nation is building, it is clear that the various challenges to fixing the conditions of society will also have an impact on the money market. In the past, the internal situation in the stock exchanges in Indonesia was considered to be very weak, the stock market capitalization was small because of the limited mobilization of domestic funds by investment managers. This is if measured from the comparison with other exchanges in the Asia Pacific region. Such conditions occur due to a system of work that is less supportive, as well as unclear goals, especially the public's own support which seems to be half-baked due to inaccurate information and knowledge about the stock exchange is not yet in the community. All of that finally continues to be addressed so that the stock exchange is created with rapid development. In the course of the rapid growth of the stock market, it is sometimes colored by bullish and bearish conditions. The exchange condition is called bullish, namely the stock price index continues to rise for a certain period of time, and this can arise along with a healthy economic situation, income increases, the industry and trade grow well. While the condition of the exchange is called bearish if the stock price index continues to decline. All of this was also a result of 
a sluggish economic situation and monetary policy which resulted in a monetary crisis, the circulation of money stuttering.

The development of capital markets in many countries is caused by the many benefits that can be given to the development of a country's economy. These benefits include: ${ }^{1}$

1. Improving the Capital Structure of the Company

The company can increase its capital not only in the form of loans / loans, but it has also been possible in the form of equity through the issuance of shares in the capital market. Therefore, for companies that have overleverage, they can reduce the level of leveraging through the issuance of shares. In this way the company's capital structure will be more healthy.

2. Increasing the Efficiency of Allocation of Funding Resources

With the availability of various capital market instruments, companies will get wider alternatives to get the lowest cost funds. Therefore, the capital market has the function of creating more efficient sources of funds.

3. Supporting the creation of a healthy economy

Having the need to disclose in the capital market will give birth to a culture of fairness which will then create good business behavior in the capital market, so that it will affect the creation of a healthy economy.

4. Increasing Community Participation

Increasing public participation in development through the capital market, the community is allowed to own shares of companies that go public. Funds obtained by the company will be used for business development which will then be able to increase national production.

5. Open the Divestment Alternative

The capital market allows local and foreign investors to divest when investors want to no longer invest in certain sectors.

6. Increasing State Revenues

Through solid capital, state revenues through tax collection can be further enhanced. This is possible because the development of the capital market will spur openness which in turn can encourage the compliance of issuers as taxpayers. In addition, the greater the transaction on the exchange, the greater the potential for tax collection on the transaction.

7. Can Reduce Private Foreign Debt

In line with the increase in per capita income of the community, it is time for the need for development financing not only to be obtained from foreign debt, but can be fulfilled through mobilizing public funds in the capital market. Thus, reduced external debt, especially the private sector, can reduce balance of payments pressures.

8. Arena for Youth Generation of Youth

The capital market can be used as a medium for the younger generation to participate in building a national economy with a spirit and spirit that

Sjahputra, Imam. “ Hukum Pasar Modal: Teori dan Kasus”, Harvarindo, Jakarta, 2001, hal: 56. 
is dynamic and courageous in facing challenges enabling young people to develop capital markets that require a dynamic, creative, courageous decision and ready to take risks in facing challenges. Therefore, youth participation is very much needed in the effort to develop the capital market.

The capital market is one of the important elements and a benchmark for the progress of a country's economy. One of the characteristics of developed and new industrialized countries is the existence of a well-developed and well developed capital market. From the Composite Stock Price Index (CSPI), we can know the condition of each company listed on the stock exchange. JCI can also reflect the economic conditions of a country. The sharp decline in the JCI indicated a country experiencing an economic crisis. The capital market can also be used as a means to invite the entry of foreign investors and foreign funds to help the country's economy.

Issuer companies that want to increase business capital can conduct a public offer (go public) and sell their shares to the stock exchange. Public offering is an activity carried out by an issuer to sell securities to the public, based on procedures governed by the law and its implementing regulations. This activity is more popularly called go public. Issuer is a party (company) that conducts a public offering with the aim of obtaining funds through the capital market. Whereas people who provide funds to companies by buying shares or bonds issued and sold by companies are referred to as investors. As for what is the purpose of going to a public company due to several things, namely: expansion, improving the capital structure, transfer of shareholders, etc.

Public offering (public offering) is an activity carried out by the company to obtain funds from the investor community by selling shares or bonds. ${ }^{2}$ Public Offerings are often also known as go public. By going public the company gets funds according to the needs of the company. In addition to obtaining benefits in the form of additional funds or capital for business development, issuers get several other benefits by going public, namely: issuers are better known to the public and companies are required to work more professionally because issuers get supervision from many parties such as the Stock Exchange, analysts and shareholders. ${ }^{3}$

A company that will go public where the company conducts an initial public offering (IPO) of its shares through a securities company that becomes an underwriter and through designated sales agents. IPOs are securities offering activities carried out by issuers to sell securities to the public (public) through the capital market. Investors can make purchases by ordering through underwriters or selling agents. In general, the number of shares obtained usually tends to be less than the order. This is because investors' interest in buying shares when IPO is usually very large so that allotment is done.

In Indonesia, the procedure of a company to go public follows the three main stages set by the Capital Market Supervisory Agency (BAPEPAM-LK). The first

\footnotetext{
2 Asosiasi Guru Ekonomi. "Bab. 3. Penawaran Umum di Pasar". http://asosiasiguruekonomi.files.wordpress.com/2010/11/bab_ 3_penawaran_umum_di_pasarperdana.pdf, hal: 21 .

3 Ibid.
} 
stage is self preparation, then the second stage is obtaining a registration permit from BAPEPAM-LK, and the third is conducting an initial public offering and entering the secondary market by listing its securities on the stock exchange. ${ }^{4}$

Looking at the dynamic development of IPOs in Indonesia, the authors are very interested in writing about the capital market, especially regarding public offerings or going public. For this reason, the author makes PT. Dian Swastatika Sentosa Tbk (PT. DSS Tbk) as the object of research. PT. DSS Tbk has several subsidiaries that have and / or go public, among others, in the mining sector.

By conducting an IPO, PT. DSS Tbk obtains large amounts of fresh funds and is received in whole / at once (not through terms). Of course this facilitates the management of PT. DSS Tbk in regulating and allocating fresh funds.

On December 10, 2009, PT. DSS Tbk conducted an initial public offering and listed its shares of 770,552,320 shares on the Indonesia Stock Exchange with an IPO price of Rp 1,500 per share. The results of the public offering were used to invest in coal mining by taking over $99.99 \%$ of the shares of PT. Bumi Kencana Eka Sakti, which includes several coal mining concessions in Sumatra and Kalimantan, including PT. Borneo Indobara and PT. Kuansing Inti Makmur / KIM Block. $^{5}$

PT. BIB is the holder of the Coal Mining Concession Work Agreement (PKP2B) located in Tanah Bumbu Regency, South Kalimantan Province. The total area of PT. BIB is 24,100 ha, with a total coal reserves of 746 million tons. Meanwhile, KIM block is the holder of a Production Operation Mining Business License located in Bungo Regency, Jambi Province. The total area of KIM Block is 2,610 ha, with a total coal reserve of 80 million tons. ${ }^{6}$

\section{Literature Review \\ 2.1 Capital Market}

Market is a means that brings together the activities of buyers and sellers for a commodity or service. Price formation occurs because there is a match between demand and supply. Market function = creating liquidity through price mechanism. ${ }^{7}$

According to Hariyanti and Serfianto, ${ }^{8}$ the capital market is a market where trades of various long-term financial instruments can be traded, such as stocks (equity / participation), bonds (bonds), mutual funds, derivative products, and other instruments. The capital market is a funding tool for companies and government institutions, as well as a means for people to carry out investment activities. Thus the capital market facilitates various facilities and infrastructure for buying and selling securities and other related activities. Instruments traded on the capital

\footnotetext{
4 Kurniawati, Bernadeta Anggreni Dian. 2001. "Studi Peristiwa (Event Study) Penawaran Saham Perdana PT. Garuda Indonesia".http://nenygory.wordpress.com/2011/08/11/studiperistiwa-event-study-penawaran-saham-perdana-pt-garuda-indonesia/ Laporan Tahunan PT. Dian Swastatika Tbk, Tahun 2009 Manajemen PT. DSS Sjahputra Imam, DR, Hukum Pasar Modal: Teori dan Kasus, Harvarindo, Jakarta, 2001, hal: 56.

8 Hariyanti dan Serfianto. "Buku Pintar Hukum Bisnis Pasar Modal”. Visimedia, jakarta, 2010, hal: 8.
} 
market are long-term instruments (more than one year), namely: stocks, bonds, mutual funds, and various derivative instruments such as: options, futures, warrants, rights, etc.

According to the Capital Market Law No. 8 of 1995 referred to as Capital Market is an activity concerned with Public Offering and Securities trading, Public Companies relating to Securities issued and institutions and professions related to Securities. The capital market has an important role for the progress of the economy of a nation, which is a means for companies to get funds from the investor community. Funds obtained from the capital market can be used to develop funds.

bangan business, paying debt, adding working capital, etc.

In general, the notion of capital markets is a market that brings together parties who have excess funds (investors) or parties that lend (lenders) and those who need funds as a borrower (borrower). Whereas according to Law No. 8 of 1995, Chapter I Article 1 Item 13 concerning Capital Market states that: "The Capital Market is an activity concerned with public offering and securities trading, public companies relating to securities issued and institutions and professions related to securities".

According to Anoraga and Pakarti (2001) the capital market is complementary in the financial sector to two other institutions, namely banks and financial institutions. The capital market provides its services, namely bridging the relationship between capital owners in this case is called an investor with a borrower of funds which in this case is called an issuer (a company that goes public). According to Jogiyanto (2000) the capital market is a place to meet between sellers and buyers with the risk of profit or loss. Short-term needs are generally obtained from the money market. The capital market is a company means to increase long-term funding needs by selling shares or issuing bonds.

From some of the terms of the capital market, it can be explained that the capital market is a market in its concrete form, which is a stock exchange which is a place to conduct securities trading activities. The definition of securities here states that the commodity traded is long-term securities that can be in the form of stocks, bonds or other securities such as right or warrant certificates.

\subsection{Stock Exchange}

The Securities Exchange is the party that organizes and provides a system and / or means to bring together securities buying and selling offers of other parties with the aim of trading securities between them. Based on this provision, it is known that the stock exchange is an institution or company that organizes or provides market system facilities to bring together securities buying and selling offers between various companies or individuals involved in the purpose of trading securities of companies listed on the stock exchange.

Stock exchanges have several tasks, including:

a. Organizing regular, fair and efficient securities trading

b. Providing supporting facilities and overseeing the activities of the members of the Stock Exchange 
c. Arrange the draft annual budget and the use of profit from the Stock Exchange, and report it to Bapepam-LK In Indonesia, there were initially two stock exchanges, namely the Jakarta Stock Exchange (BEJ) and the Surabaya Stock Exchange (BES), which in 2008 were modified to become the Indonesia Stock Exchange (IDX) located in Jakarta. Those who are stock exchange shareholders are companies that have obtained business licenses as securities brokers.

In running the stock exchange activities, a securities company is required. A Securities Company is an institution that can carry out activities as a securities broker, securities underwriter, investment manager, investment advisor and other activities in accordance with the provisions stipulated by Bapepam-LK. Securities companies as institutions of public trust have a strategic role in maintaining the continuity of the Capital Market. Therefore, the capital market authority, namely Bapepam-LK, has established various operational provisions in conducting Securities Company activities.

\subsection{Initial Public Offering (IPO)}

According to Wikipedia, an initial publik offering (IPO) or stock market launch, is the first sale of stock by a company to the publik. It can be used by either small or large companies to raise expansion capital and become publikly traded enterprises. Many companies that undertake an IPO also request the assistance of an investment banking firm acting in the capacity of an underwriter to help them correctly assess the value of their shares, that is, the share price. ${ }^{9}$

Initial public offerings or Initial Public Offering (IPO), better known as go public, are the activities of the sale of initial shares by a company to the public (public) in the capital market. Law of the Republic of Indonesia No. 8 of 1995 concerning the Capital Market defines that: "Public Offering is an activity of securities offering carried out by an issuer to sell securities to the public based on the procedures stipulated in this Law and its implementing regulations". ${ }^{10}$

Funds generated from public offerings are used for various needs, including:

1. Expansion. In the life of a company it will be endeavored to expand in its operations. This expansion can be in the form of increasing production capacity or diversifying product types.

2. Improve Capital Structure. A company's capital consists of its own capital (equity) and loan capital. Every loan must of course pay interest. Sometimes companies suffer losses only because the burden of loans, especially loans from foreign currencies, in times of depreciation of the rupiah.

3. Transferring Shareholders (Divestment)

9 Wikipedia. “Initial Publik Offering”. http://en.wikipedia.org/wiki/Initial_publik_offering

10 Handayani Sri, Tesis: “Analisa Faktor-faktor Yang Menpengaruhi Underpricing Pada Penawaran Umum Perdana (Studi Kasus Pada Perusahaan Keuangan yang Go Publik di Bursa Efek Jakarta Tahun 2000-2006)”. Program Studi Magister Manajemen - Uversitas Diponorogo. Semarang, 2008, hal: 21. 
4. Companies that go public are companies that are legally and real operating / running their businesses, which of course already have owners and shareholders. With certain considerations, sometimes the shareholders want to release / transfer shares owned to other parties. This is easy to do if there are already parties who are willing to buy it, but if not, then the shareholders can choose the capital market as a place to offer their shares in general (public offering). The transfer of shares from old shareholders to new shareholders is referred to as divestment.

\section{Discussion and Results of Research}

PT. DSS Tbk was established on August 2, 1996 based on Company Establishment Deed No. 6 dated August 2, 1996, then amended by Amendment Deed No. 35 dated October 8, 1996 where the two deeds were made by Linda Herawati, S. H., Notary in Jakarta. The deed of establishment and amendment has been approved by the Minister of Justice of the Republic of Indonesia based on Decree No. C2-9854.HT.01.01.TH'96 dated October 28, 1996 and has been registered in the list of companies in accordance with UUDWDP with TDP No. 09011609914 at the Kodya North Jakarta Company Registration Office No.83 / BH.09.01 / XII / 96 dated December 28, 1996 and announced in the State Gazette of the Republic of Indonesia No. 46 dated June 10, 1997 Supplement No. 2258.

PT. DSS Tbk started commercial business activities on January 2, 1998. The first business of PT. DSS Tbk is by providing electricity and steam power services to the pulp and paper factory of PT. Indah Kiat Pulp and Paper and PT. Pindo Deli. At present, PT. DSS Tbk has 4 (four) power plant complexes located in the respective locations of the pulp and paper factories with a total production capacity of $300 \mathrm{MW}$ for electricity and 1,336 tons / hour for steam supply. This complex of plants is in the area of Tangerang, Serang, and Karawang. For the operation and maintenance of the power plant, PT. DSS TBk already has an ISO 9001: 2000 Quality Management System.

The business development of PT. DSS Tbk continues. December 30, 2004, PT. DSS Tbk merged with PT. Supra Veritas (SV) where SV is a company that transfers property (transferor company), while PT. DSS Tbk is a company that receives surviving company / acquiring company. Since the merger, PT. DSS Tbk conducts business activities in the field of trading in pulp, paper and chemicals.

In 2007, PT. DSS Tbk began investing in the provision of BTS towers by building 270 BTS towers. A year later, PT. DSS Tbk began to lease its BTS towers to PT. Smart Telecom as the main tenant. Until now, PT. DSS has 1,105 BTS towers spread across Java, Bali and Lombok.

In April 2009, PT. DSS expanded by buying RCI, a company that invests in mining companies, PT. Borneo Indobara.

In 2009, PT. DSS Tbk invests in coal mining by taking over $99.99 \%$ of the shares of PT. Bumi Kencana Eka Sakti, where the investment includes several coal mining concessions on the islands of Sumatra and Kalimantan, including PT. Borneo Indobara and PT. Kuansing Inti Makmur / KIM Block, where the two PTs are subsidiaries of PT. Bumi Kencana Eka Sakti. 
As a company that is oriented towards growing into the future and always responsive to the opportunities that exist, PT. DSS Tbk views the current business sector, especially in the energy and infrastructure sectors, has a positive long-term outlook and is supported by an increasing demand trend.Berikut prospek usaha unitinit bisnis PT. DSS Tbk:

\section{a. Energy Provider Business Unit}

Electricity needs always have a rising graph from time to time in line with the growth of the community and its usage industry. In Indonesia, PLN as the only National Electricity Company has not been able to meet $100 \%$ of domestic electricity needs due to limited power, networks and resources.

The average electricity consumption growth per year based on PLN electricity consumption data for 2001-2006 is 6\%. Meanwhile, on the other hand there are still many regions in Indonesia that have not yet received electricity from PLN, so that PLN must establish cooperation in purchasing electricity with several private power plants

Likewise with the needs of the industrial world for electricity, not all of them can be fulfilled by PLN, while the urgency is very urgent because it deals with not small investments.

Seeing the above conditions, with government support in the form of private electricity programs and the existence of long-term contracts with customers, the electricity business has the certainty of the prospects and long-term business continuity.

\section{b. Trading Business Unit}

In line with the global and domestic economic recovery and the ongoing era of free trade, global and domestic trade activities are expected to continue to increase in the future.

\section{c. Telecommunication Tower Business Unit}

The cellular industry in Indonesia is estimated to require 158,000 BTS towers within the next 5 (five) years. Meanwhile, the availability of BTS towers in 2008 according to the Association of Telecommunication Tower Infrastructure Developers was only around 60,000 units. On the other hand, cellular operators face constraints of limitations and time in building BTS. Thus, high demand is created and the BTS industry has good business prospects.

\section{d. Coal Mining Business Unit}

For coal mining, many factors influence trends in the world coal market, among other things: the increase in urbanization, electrification and security problems. In this case, coal experienced the fastest growth as a source of energy consumed, compared to natural gas, hydropower, petroleum and nuclear. Estimated to enter the year 2025, world demand for the world has increased by around 55\% compared to today, exceeding demand for natural gas, hydropower, wind, nuclear 
and diesel. In Indonesia alone, coal began to become the most energy source used in producing electricity.

Based on data from the 15th Annual Asia Coaltrans on May 31 - June 3, 2009, coal demand growth in the Atlantic and Pacific region has increased rapidly. It is projected that demand for coal in this region will increase by $13 \%$ over a 4 -year period, from 735 million tons in 2009 to 832 tons in 2013. The largest growth will be coal demand in the South Asia region, which is $69 \%$ from 2009 to in 2013, which was then followed by the Southeast Asian region. The mapping is enough to illustrate that coal consumption has a high growth rate, and coal businesses have attractive market opportunities.

In Capital Market Law No. 8 of 1995, the capital market is defined as activities related to Public Offering and Securities trading, Public Companies relating to Securities issued, as well as institutions and professions related to Securities. From the definition above, it is clear that the Capital Market Supporting Institutions and professions are an integral part of the Capital Market industry itself, from public offerings to various other issuers' activities on the secondary market.

In particular, the role of Institutions and Supporting Professionals is needed in the process of public offering activities for shares. The existence of supporting institutions and professions is strategic in the framework of the formation of a capital market system of insurers which is essentially an industry of trust based on information disclosure (full disclosure).

Support provided by supporting institutions and professions makes the public offering process work well in accordance with the expectations of the parties involved, such as issuers that issue shares and investors who will buy the shares. With the support of information and opinions provided by supporting institutions and professions, the issuer can optimally achieve the expected goals and investors get information relevant to investment considerations.

It should be noted that all institutions and supporting professions engaged in the capital market must be registered with Bapepam-LK and of course first registered in their respective professional associations, for example, registered at IAI for public accountants, noratis at the Indonesian Notary Association, and so on.

Institutions and Supporting Professionals that help and play a role in the IPO of PT. DSS Tbk is as follows:

\section{Public Accountants}

Public Accountants who help and play a role in the IPO of PT. DSS Tbk is Mulyamin Sensi Suryanto, through a letter of appointment No. 621 / VII / 2009 / GA / ES / MSS dated 12 June 2009. The duties and obligations of Mulyamin Sensi Suyanto in the IPO of PT. DSS is conducting audits based on auditing standards set by the Indonesian Institute of Accountants.

The audit conducted by Mulyamin Sensi Suyanto includes examining on the basis of testing evidence supporting the amounts and disclosures in the financial report and also evaluating on the basis of accounting principles used and significant estimates made by management regarding the assessment of the financial presentation of PT. DSS Tbk as a whole. 
In a complete prospectus, information or obtained from Mulyamin Sensi Suryanto, namely the financial statements of PT. DSS Tbk for the last few years (historical) and financial projections of PT. DSS Tbk for the next few years. Information or opinion of Mulyamin Sensi Suryanto will provide a belief for other parties to the financial statements issued by the issuer.

2. Legal Consultant

Legal Consultants who help and play a role in the IPO of PT. DSS Tbk is Makes \& Partners, through Appointment Letter No. 006 / DSS / FIN / 2009 dated January 15, 2009. The main duties and obligations of Makes \& Partners in the IPO of PT. DSS Tbk is conducting checks and research on the facts that exist about PT. DSS Tbk and other related information as stated by PT. DSS Tbk is viewed from a legal perspective.

Examination of legal facts conducted by Makes \& Partners includes:

a. Articles of Association of PT. DSS Tbk and its changes

b. Business license of PT. DSS Tbk

c. Proof of ownership / control of PT. DSS Tbk

d. Engagement of PT. DSS Tbk with other parties

e. Cases both civil and criminal concerning PT. DSS Tbk and personal managers of PT. DSS Tbk

It can be concluded that, the purpose of the opinion of Makes \& Partners (Legal Consultant) is to provide an accurate description or information regarding the legal aspects of PT. DSS Tbk such as articles of association and amendments, chronology of shareholders, proof of control over assets of PT. DSS, engagement with other parties and cases that are being faced by PT. DSS Tbk.

The results of the examination and legal opinions are contained in the legal aspect inspection report, which is the basis of the Legal Opinion given objectively and independently, based on the code of ethics, professional standards and applicable capital market regulations.

\section{Appraisal Company}

Appraisers who help and play a role in the IPO of PT. DSS Tbk is PT. Satyatama Graha Tara, through the Appointment Letter No. 0330 / SGT-C-C / HM / 05/09 May 29, 2009.

The main duties and obligations of PT. Satyatama Graha Tara in the IPO of PT. DSS Tbk is giving an assessment of the fair market value of shares and opinions on the fairness of the transaction value with the planned transaction of PT. DSS Tbk by referring to the Professional Standards and applicable Capital Market Regulations.

Services of PT. Satyatama Graha Tara plays an important role in the process of going public PT. DSS Tbk because PT. DSS Tbk wants to look "beautiful" through large asset values such as tangible assets of the company, while on the other hand, investors want an objective valuation of the tangible assets of the company, for which PT. DSS Tbk requires the services of PT. Satyatama Graha Tara to assess tangible assets of PT. DSS Tbk through agreed upon measurements and methods and objectives to determine the fair value of the company's tangible assets. By 
knowing the reasonable asset value, the players in the capital market can project the price or value of PT. Reasonable DSS Tbk reflected in the fair value of shares to buy.

\section{Securities Administration Bureau}

Securities Administration Bureau which assisted and played a role in the IPO of PT. DSS Tbk is PT. Sinartama Gunita (affiliated), through Appointment Letter No. 007 / SP-DSS / IX / 09 / hs dated 7 September 2009.

The duties and responsibilities of PT. Sinartama Gunita as the Securities Administration Bureau in the IPO of PT. DSS Tbk is administering stock orders in accordance with the applications available at the Securities Administration Bureau in accordance with the applicable Professional Standards and Capital Market Regulations, including receipts and stock orders in the form of List of Share Purchases (DPPS) and Formulations of Share Purchase Orders (FPPS) which have been equipped with documents as indicated in the stock order and have been approved by the Underwriter as an order submitted for the allotment of shares. Administering stock orders according to the application available at the Registrar. Together with the Underwriters, BAE has the right to refuse stock orders that do not meet the booking requirements by taking into account the applicable regulations.

In the event that an order exceeds the number of shares offered, the Registrar conducts the allotment process based on the allotment formula set by the Underwriter, prints the allotment confirmation and prepares the allotment report. The Registrar is also responsible for issuing the Allotment Confirmation Form (FKP) on behalf of the subscriber who received the allotment and compiled the Initial Public Offering report with the guidelines of the applicable capital market legislation.

\section{Notary}

Notary who helped and played a role in the IPO of PT. DSS Tbk is Linda Herawati, S.H, through a letter of appointment No. 005 / SPNP-DSS / I / 09 / ds / a dated January 15, 2009.

The scope of the Notary's duties as a supporting profession in the framework of the IPO of PT. DSS, among others, prepared and made deeds in the framework of the IPO, including changes in the entire Articles of Association of PT. DSS, Securities Underwriting Agreement, and Courts Management of Stock Administration based on Notary Position Regulations and Notary Code of Ethics.

6. Constraints in the Implementation of the IPO of PT. Dian Swastatika Sentosa Tbk

To find out whether in the IPO process of PT. This DSS Tbk has obstacles that will interfere with the IPO process. A reference is needed based on the Capital Market Law. Basically all the provisions stipulated in the Capital Market Law have been fulfilled in the IPO process of PT. DSS Tbk.

Some small things sometimes require special scrutiny and handling. Some of these include bureaucratic issues related to the licensing sector both in the mining 
and capital market fields. For example, when the IPO reaches the registration stage, it coincides with the local government policy that requires an evaluation or reevaluation of the AMDAL documents in the District, and before an evaluation by the relevant local government is carried out, the AMDAL document is declared invalid. This is certainly very disturbing in the IPO process. As is known that the process of assessing or evaluating the AMDAL document requires approximately 3 (three) months. In these conditions, the role of Bapepam-LK institutions is very necessary to be able to provide strategic policies. The policy is a dispensation if the results of the discussion of the AMDAL Document state that it is accepted, then the statement stating that the AMDAL document is in process can be used as the basis for the next IPO process.

\section{Conclusion}

From the aspect of Capital Market Law, the IPO conducted by PT. Dian Swastatika Sentosa Tbk (PT. DSS Tbk) is legitimate and has complied with all the provisions governing this matter. This can be seen in a series of stages of the IPO implementation carried out by PT. DSS Tbk. Likewise, if viewed from the legal aspects of Mineral and Coal Mining, it does not indicate any contradiction with the article governing Coal Mining if it is associated with the IPO process of PT. DSS Tbk. In conducting the IPO, PT. DSS Tbk does not experience significant obstacles. The only obstacles faced are small bureaucratic obstacles and policies can be overcome by the active role of Bapepam-LK. This shows that Bapepam-LK has acted as a dynamic supervisor.

\section{References}

Arkebaiuer B. James and Schultz Ron, 1998. Going Public: Everything You Need to Know to Take Your Company Public, Including Internet Direct Public Offering. Dearborn Financial Publishing, Inc.

Asosiasi Guru Ekonomi. "Bab. 3 Penawaran Umum di Pasar". http://asosiasiguru ekonomi.files.wordpress.com/2010/11/bab_3_penawaran_umum_di_pasarp erdana.pdf. 13 Februari 2012.

Bapepam. "Sejarah Pasar Modal". http://www.bapepam.go.id/old/profil/sejarah.htm. 8 Maret, 2012.

Fabozzi J. Frank and Modigliani Franco, 2003. Capital Markets: Institutions and Instruments, Third Edition. Prentice Hall.

Fakhruddin M. Hendy, 2008. Go Publik: Strategi Pendanaan dan Peningkatan Nilai Perusahaan. Jakarta: PT. Elex Media Konmputindo.

Fakhruddin M. Hendy dan Basir Saleh, 2004. Aksi Korporasi: Strategi Peningkatan Nilai Saham, Edisi 1. Jakarta: SalembaEmpat.

Handayani Sri, 2008. Tesis: Analisa Faktor-faktor Yang Menpengaruhi Underpricing Pada Penawaran Umum Perdana (Studi Kasus Pada Perusahaan Keuangan yang Go Publik di Bursa Efek Jakarta Tahun 2000-2006). Program Studi Magister Manajemen - Uversitas Diponorogo. 
Hariyanti dan Serfianto, 2010. Buku Pintar Hukum Bisnis Pasar Modal. Jakarta: Visimedia

Kurniawati, Bernadeta Anggreni Dian. 2001. "Studi Peristiwa (Event Study) Penawaran Saham Perdana PT. Garuda Indonesia". http://nenygory. wordpress.com/2011/08/11/studi-peristiwa-event-study-penawaran-sahamperdana-pt-garuda-indonesia/. 12 Maret 2012.

Laporan Tahunan PT. Dian Swastatika Tbk, Tahun 2009

Penawaran Umum Saham Perdana, Paparan Publik, Tahun 2011

Peraturan Bapepam No. IX. F. 1 Tentang Penawaran Tender.

Peraturan Bapepam No. IX.C.2 tentang Pedoman Mengenai Bentuk dan Isi Prospektus dalam Rangka Penawaran Umum.

Pramono, Nindyo, 1997. Sertifikasi Saham PT Go Public \& Hukum Pasar Modal Indonesia. Bandung: PT. Aditya Bakti

Rini, William A, 1999. The Basic of Stocks, Bonds, and Options. William A. Rini Publishing.

Sjahputra, Imam, 2001. Hukum Pasar Modal: Teori dan Kasus. Jakarta: Harvarindo

Sulistyowati, 2010. Aspek Hukum dan Realita Bisnis Perusahaan Group di Indonesia Jakarta: Erlangga.

Taviati dan Qamariyanti Yulia, 2009. Hukum Pasar Modal di Indonesia. Jakarta: Sinar Grafika

Undang-undang No. 4 Tahun 2009 Tentang Pertambangan Mineral dan Batubara.

Undang-undang No. 8 Tahun 1995 Tentang Pasar Modal.

Undang-undang No.40 Tahun 2007 Tentang Perseroan Terbatas.

Wikipedia. “Initial Public Offering”.http://en.wikipedia.org/wiki/Initial_public _offering. 15 Februari 2012.

Zed Mestika, 2004. Metode Penelitian Kepustakaan. Jakarta: Yayasan Obor Indonesia 